Available online at GSC Online Press Directory

GSC Biological and Pharmaceutical Sciences

e-ISSN: 2581-3250, CODEN (USA): GBPSC2

(RESEARCH ARTICLE)

\title{
Assessment of the suitability of water quality for irrigation in Ogbomoso, Oyo State
}

\author{
Adegbola Gbolagade Adeyemi *, Dauda Muhammed and Aluko Timothy Oludare \\ Forestry Research Institute of Nigeria, Southern Guinea Savanna Research Station, P.O. Box 209, Mokwa, Niger State.
}

Publication history: Received on 06 October 2019; revised on 23 October 2019; accepted on 27 October 2019

Article DOI: https://doi.org/10.30574/gscbps.2019.9.2.0191

\begin{abstract}
The perpetual decline of the quality of available surface water resources due to increasing global pollution menace necessitates the needfulness for suitability assessment of river water resources for irrigation purposes. Water samples were collected during the dry season (November, 2018) and wet season (July, 2019) into sterilized, labelled bottles and were transported in ice packed to laboratory for analyses. Results showed the $\mathrm{pH}$ 6.87-6.91, calcium 36-38 mg/l, magnesium 8-9 mg/l, potassium 2.40-2.50 mg/l, sodium 1.28-1.46 mg/l, bicarbonate constant at $180 \mathrm{mg} / \mathrm{l}$, phosphate $0.08-0.11 \mathrm{mg} / \mathrm{l}$, electrical conductivity constant at $0.06 \mathrm{mg} / \mathrm{l}$, Nitrate $0.04-0.41 \mathrm{mg} / \mathrm{l}$, sulphate $26-28 \mathrm{mg} / \mathrm{l}$, total dissolved 33.30-34.10 mg/l, chloride 7.5-9 mg/l for the dry season and the pH range of 7.15-7.33, calcium 30-32 mg/l, magnesium 17-18 mg/l, potassium 2.70-2.80 mg/l, sodium 1.86-1.88 mg/l, bicarbonate 290-295 mg/l, phosphate 0.11$0.12 \mathrm{mg} / \mathrm{l}$, electrical conductivity $0.13-0.14 \mathrm{mg} / \mathrm{l}$, Nitrate constant at $0.07 \mathrm{mg} / \mathrm{l}$, sulphate $35-36 \mathrm{mg} / \mathrm{l}$, total dissolved solid 64.30-67.50 mg/l, chloride $12-14 \mathrm{mg} / \mathrm{l}$ for the rainy season. Most of the samples analyzed were within the recommended limits set by [22], [13] for irrigation water standard. The water quality indicators SAR,0.05; SSP,2.28; KR,0.02; PI,78.03; RSC1.37 for dry season and SAR, 0.07; SSP, 2.62; KR, 0.03; PI, 73.28; RSC, 1.79 for rainy season were under safe limits.
\end{abstract}

Keywords: Irrigation; Surface water; Quality; Dry season; Rainy season

\section{Introduction}

Water is an important source of life which is extremely essential for survival of all living organisms. Water is one of the abundantly available substances in the nature which men have exploiting more than any other resources for the sustenance of life. Life is impossible on this planet without water, our most important resource apart from air and land. Surface water, especially rivers is part of the source of water available to the people in general. The visible bodies of water are referred to as surface water. These are essential water for achieving good agricultural produce and to attain standard food security in developing countries in the world. Water has become a universal issue, not only in terms of the availability of its quantity alone, but also its quality [15]. However, the total water amount on the earth is about 1.35 billion cubic kilometers. About 97.1 per cent has been locked into oceans as saltwater. Ice sheets and glaciers have arrested 2.1 per cent. Only 0.2 per cent is the fresh water present on the earth, which can be used by human for varieties of purpose. Remaining 0.6 per cent is in underground form [37]. The qualities of these water bodies vary widely depending on the location and environmental factors [4].

However, it is quality varies from place to place and season to season. Adequate and safe water supply is therefore a pre-requisite for significant socio-economic development of any community. Unfortunately, in many areas of the world, especially developing countries including Nigeria, it is not easy to obtain a steady source of water for agricultural uses. Water quality is a term used to describe the physical, chemical and biological parameters of water features concerning its standard for specific usage [40].

\footnotetext{
${ }^{*}$ Corresponding author

E-mail address: adeyemi.adegbola9@gmail.com
} 
Moreover, the quality of irrigation water is directly related to its effects on both the crops and soils on which they are grown as well as its management, thus high quality crops can only be achieved by using standard irrigation water. Water for irrigation varies greatly in quality relating to the total quantity of dissolved salts and its ionic composition in relation to the source of the water [1], [20], its location and time of sampling [15]. The quality of water is generally affected by diffuse contamination originating from intensive irrigated agriculture [38]. It is a well-known fact that a polluted environment has a detrimental effect on health of people, animal life and vegetation [36]. The features of irrigation water that define its quality vary with the source of the water [20]. The Water quality of any specific area or specific source can be assessed using physical, chemical and biological parameters. The values of these parameters are harmful to crop growth if they exceed certain threshold values. Therefore, the objective of the present study was to assess the suitability of Oba river water quality in the study area with respect to $\mathrm{pH}$, Electrical Conductivity (EC), Total Dissolve Solids (TDS), Sodium Adsorption Ratio (SAR) and specific ions such as Sodium ( $\mathrm{Na}+$ ), Magnesium $\left(\mathrm{Mg}^{2+}\right)$, $\left.\mathrm{Calcium}_{(\mathrm{Ca}}{ }^{2+}\right)$, Potassium $\left(\mathrm{K}^{+}\right)$, Bicarbonate $\left(\mathrm{HCO}_{3}{ }^{-}\right)$, Chloride $\left(\mathrm{Cl}^{-}\right)$,Sulphate $\left(\mathrm{SO}_{4}{ }^{2-}\right)$ and Nitrate $\left(\mathrm{NO}_{3}{ }^{-}\right)$and hence to ascertain their suitability for irrigation purpose.

\section{Material and methods}

\subsection{Description of the study area}

The experiment has been conducted in Oba river in Ogbomoso land. Ogbomoso located on Latitude $8^{\circ} 10^{\prime} \mathrm{N}$ and Longitude $4^{\circ} 10^{\prime} \mathrm{E}$, about $342 \mathrm{~m}$ above the mean sea level, southwest Nigeria. The study area has a bimodal rainfall pattern, with rainfall peaks in the months of June and September and break in August, with mean annual rainfall of approximately $1200 \mathrm{~mm}$ while the mean maximum temperature was not above $33^{\circ} \mathrm{C}$ and minimum temperature not below $16^{\circ} \mathrm{C}$. The relative humidity of the area is not less than $80 \%$ between the months of April-November while it is low between December-March when dry wind (harmattan) blows from the northeastern part of the country [39].

\subsection{Sample collection and analysis}

Oba River was visited as early as 7:00 am for samples collection for analyses. Sampling were collected and taken to laboratory for the analysis of physiochemical properties. This research work conducted in November, 2018 for the dry season and July, 2019 for the rainy season. During each sampling, six replicates of water samples were collected in sterilized bottles at different points along Oba river in Ogbomoso. After sampling, the bottles were marked, sealed and taken to the laboratory in ice-packed container for further analyses. The water quality indicators that were analyzed are: EC, $\mathrm{Ca}^{2+}, \mathrm{CO}_{3}, \mathrm{HCO}_{3}^{-}, \mathrm{K}^{+}, \mathrm{Mg}^{2+}, \mathrm{Na}^{+}, \mathrm{pH}, \mathrm{PO}_{4}, \mathrm{SO}_{4}, \mathrm{NO}_{3}, \mathrm{Cl}$, and TDS (All analyses was done according to [30] standard method. The concentrations of $\mathrm{Na}^{+}, \mathrm{Ca}^{2+}$ and $\mathrm{Mg}^{2+}$ were used to quantify the sodium adsorption ratio (SAR) according to the equation.

\subsection{Statistical analysis}

The results obtained was subjected to descriptive statistics to determine the minimum, maximum, mean, standard deviation and coefficient of variation of the pooled data, irrespective of sampling points and sampling period. Raw data and computed water quality indicators was subjected to analysis of variance (ANOVA) and means was separated by using Fisher`s least significant difference (LSD) test at 5\% level of probability. All analyses were performed by using SPSS (v. 20) and Grapher (version 10.0) software.

\subsection{Analysis of water samples}

Sample Analysis of Oba river in Ogbomoso was done for the major and minor ions $\left(\mathrm{Na}^{+}, \mathrm{K}^{+}, \mathrm{Ca}^{2+}\right.$ and $\left.\mathrm{Mg}^{2+}\right)$ and anions $\left(\mathrm{NO}_{3}, \mathrm{CO}_{3}, \mathrm{HCO}_{3}, \mathrm{SO}_{4}{ }^{2-}\right.$ and $\mathrm{PO}_{4}{ }^{2-}$ ) and other chemical parameters ( $\mathrm{SAR}$ and SSP, $\mathrm{RSC}$, PI and $\mathrm{KR}$ ) have also determined using standard empirical formulas. Beside this, measurements of $\mathrm{pH}, \mathrm{EC}$, TDS were done.

\subsection{Samples test and analysis}

Methods: pH, TDS and Electrical conductivity (EC) were measured in-situ, using portable pH/EC/TDS meter H198106. Palintest photometer was used with colorimetric method to determine the following: $\mathrm{HCO}_{3}, \mathrm{CO}_{3}, \mathrm{NO}_{3}-\mathrm{N}_{,} \mathrm{SO}_{4}, \mathrm{PO}_{4}-\mathrm{P}$, $\mathrm{Ca}^{2+}, \mathrm{Mg}^{2+}, \mathrm{Na}^{+}, \mathrm{Cl}^{-}$and $\mathrm{K}^{+}$. The choice of variables or parameters analyzed was informed by their roles during crop production. Other water quality parameters and indexes necessary for irrigation practice such as Residual Sodium Carbonate (RSC), Sodium Adsorption Ratio (SAR), Soluble Sodium percentage (SSP), Permeability Index (PI) and Kelly ratio (KR) were evaluated with the following equations. 


\subsubsection{Residual sodium carbonate (RSC)}

The residual sodium carbonate was calculated simply by subtracting the quantity of $\mathrm{Ca}^{2+}+\mathrm{Mg}^{2+}$ from the sum total of carbonates and bicarbonates determined separately in a given sample and expressed in meq/l. Note that concentration in $\mathrm{meq} / \mathrm{l}=\frac{\mathrm{mg} / \mathrm{l}}{\text { Atomic weight }}$

Thus,

$$
\mathrm{RSC}=\left(\mathrm{CO}_{3}^{2-}+\mathrm{HCO}_{3}^{-}\right)-\left(\mathrm{Ca}^{2+}+\mathrm{Mg}^{2+}\right)
$$

\subsubsection{Sodium adsorption ratio (SAR)}

Sodium adsorption ratio was calculated using the formula given below. The concentrations of $\mathrm{Na}^{+}, \mathrm{Ca}^{2+}$ and $\mathrm{Mg}^{2+}$ was used to calculate the sodium adsorption ratio (SAR) according to the equation:

$$
\frac{\frac{N a^{+}}{\sqrt{C a^{2+}+M g^{2+}}}}{2}
$$

Where $\mathrm{Na}^{+}$is sodium concentration, meq/l, $\mathrm{Ca}^{2+}$ is calcium concentration, meq/l; $\mathrm{Mg}^{2+}$ is magnesium concentration, meq/l.

\subsubsection{Soluble sodium percentage (SSP)}

Wilcox (1955) has proposed classification scheme for rating irrigation water on the basis of soluble sodium percentage (SSP). The SSP was calculated by using following formula:

$$
\mathrm{SSP}=\frac{N a^{+}+\times 100}{\mathrm{Ca}^{2+}+\mathrm{Mg}^{2+}+\mathrm{Na}^{+}}
$$

Where, the concentration of ions is expressed in meq/l.

\subsubsection{Permeability index (PI)}

The permeability index was calculated by the following formula:

$$
\mathrm{PI}=\frac{\mathrm{Na}^{+}+\sqrt{\mathrm{HCO}_{3}^{-}}}{\mathrm{Ca}^{2+}+\mathrm{Mg}^{2+}+\mathrm{Na}^{+}} \times 100
$$

Where, all the values are in meq/l.

\subsubsection{Kelly's ratio $(K R)$}

Kelly's ratio was calculated by using the following expression:

$$
\mathrm{KR}=\frac{N a^{+}}{C a^{2+}+M g^{2+}}
$$

Where, concentrations are expressed in meq/l.

\section{Results and discussions}

\subsection{Descriptive statistics of water quality indicators}

The results of the minimum, maximum, mean, standard deviation and coefficient of variation of the water quality indicators evaluated for Oba River in Ogbomoso are presented in Table 1 and Table 2 for dry and rainy season respectively. 
Adegbola et al. / GSC Biological and Pharmaceutical Sciences 2019, 09(02), 021-031

Table 1 Descriptive statistics of the water quality parameters of Oba River in dry season

\begin{tabular}{llllll}
\hline Parameters & Min & Max & Mean & Cv(\%) & SD \\
\hline $\mathrm{EC}$ & 0.07 & 0.07 & 0.07 & 0.00 & 0.00 \\
$\mathrm{HCO}_{3}$ & 240 & 240 & 240 & 0.00 & 0.00 \\
$\mathrm{NO}_{3}$ & 0.04 & 0.41 & 0.16 & 130.79 & 0.21 \\
$\mathrm{SO}_{4}{ }^{2-}$ & 26.00 & 28.00 & 26.67 & 4.33 & 1.15 \\
$\mathrm{PO}_{4}$ & 0.08 & 0.11 & 0.10 & 15.80 & 0.02 \\
$\mathrm{Ca}^{2+}$ & 36.00 & 38.00 & 37.33 & 3.09 & 1.15 \\
$\mathrm{Mg}^{2+}$ & 8.00 & 9.00 & 8.33 & 6.93 & 0.58 \\
$\mathrm{Na}^{+}$ & 1.28 & 1.46 & 1.37 & 6.57 & 0.09 \\
$\mathrm{~K}^{+}$ & 2.40 & 2.50 & 2.43 & 2.37 & 0.06 \\
$\mathrm{pH}$ & 6.87 & 6.91 & 6.89 & 0.29 & 0.02 \\
$\mathrm{TDS}$ & 33.30 & 34.10 & 33.80 & 1.29 & 0.44 \\
$\mathrm{Cl}$ & 7.50 & 9.00 & 8.16 & 7.59 & 0.62 \\
\hline
\end{tabular}

Table 2 Descriptive statistics of the water quality parameters of Oba River in rainy season

\begin{tabular}{llllll}
\hline Parameters & Min & Max & Mean & Cv (\%) & SD \\
\hline $\mathrm{EC}$ & 0.13 & 0.14 & 0.13 & 0.00 & 0.00 \\
$\mathrm{HCO}_{3}$ & 290 & 295 & 293.33 & 0.98 & 2.89 \\
$\mathrm{NO}_{3}$ & 0.07 & 0.07 & 0.65 & 0.88 & 0.00 \\
$\mathrm{SO}_{4}{ }^{2-}$ & 35.00 & 36.00 & 25.33 & 1.63 & 0.58 \\
$\mathrm{PO}_{4}$ & 0.11 & 0.12 & 0.12 & 4.95 & 0.01 \\
$\mathrm{Ca}^{2+}$ & 30.00 & 32.00 & 31.00 & 3.23 & 1.00 \\
$\mathrm{Mg}^{2+}$ & 17.00 & 18.00 & 17.67 & 3.27 & 0.58 \\
$\mathrm{Na}^{+}$ & 1.86 & 1.88 & 1.87 & 0.53 & 0.01 \\
$\mathrm{~K}^{+}$ & 2.70 & 2.80 & 2.77 & 2.09 & 0.06 \\
$\mathrm{pH}$ & 7.15 & 7.33 & 7.23 & 1.27 & 0.09 \\
$\mathrm{TDS}$ & 64.30 & 67.50 & 66.30 & 2.63 & 1.74 \\
$\mathrm{Cl}$ & 12.00 & 14.00 & 12.67 & 9.12 & 1.15 \\
\hline
\end{tabular}

$\mathrm{pH}$ : degree of alkalinity and acidity; EC: electrical conductivity, $\mathrm{dS} \mathrm{m}^{-1}$; TDS: total dissolved solid, $\mathrm{mg} / \mathrm{l} ; \mathrm{Ca}^{2+}$ : calcium, $\mathrm{mg} / \mathrm{l} ; \mathrm{Mg}^{2+}$ : magnesium, mg/l;

$\mathrm{K}^{+}$: potassium, mg/l; $\mathrm{Na}^{+}$: sodium, $\mathrm{mg} / \mathrm{l} ; \mathrm{NO}_{3}-\mathrm{N}$ :nitrate-nitrogen, $\mathrm{mg} / \mathrm{l} ; \mathrm{SO}_{4^{2-}}$ : sulphate, $\mathrm{mg} / \mathrm{l} ; \mathrm{PO}_{4}{ }^{3-}-\mathrm{P}$ : phosphate-phosphorus, $\mathrm{mg} / \mathrm{l} ; \mathrm{HCO}_{3}{ }^{-}$: bicarbonate, $\mathrm{mg} / \mathrm{l}$; Chloride, $\mathrm{mg} / \mathrm{l}$; Min.: minimum; Max.: maximum; SD: standard deviation; CV: coefficient of variation

Source: Author derived 
Table 3 Guidelines for interpretations of water quality for irrigation (FAO, 1989)

\begin{tabular}{|c|c|c|c|}
\hline \multirow[t]{2}{*}{ Potential Irrigation Problem } & \multicolumn{3}{|c|}{ Degree of Restriction } \\
\hline & Use & $\begin{array}{l}\text { Slight to } \\
\text { moderate }\end{array}$ & Severe \\
\hline \multicolumn{4}{|l|}{ Salinity (affects crop water availability) } \\
\hline \multicolumn{4}{|l|}{$\mathrm{ECw}(\mathrm{dS} / \mathrm{m})$} \\
\hline \multirow[t]{2}{*}{ TDS (mg/l) } & $<0.7$ & $0.7-3.0$ & $>3.0$ \\
\hline & $<450$ & $450-2000$ & $>2000$ \\
\hline \multicolumn{4}{|l|}{$\begin{array}{lr}\text { Permeability } & \text { (affects infiltration rate } \\
\text { into soil) } & \text { ECw }\end{array}$} \\
\hline \multirow[t]{2}{*}{ adj.SAR } & $<0.5$ & $0.5-0.2$ & $<0.2$ \\
\hline & $<6.0$ & $6.0-9.0$ & $<9.0$ \\
\hline $\begin{array}{l}\text { Specific ion toxicity (affects sensitive } \\
\text { crops) Sodium (Na) as in SAR }\end{array}$ & $<3$ & $3-9$ & $>9$ \\
\hline Chloride $\left(\mathrm{Cl}^{-}\right)$Surface irrigation & $(\mathrm{meq} / \mathrm{l})<4$ & $4-10$ & $>10$ \\
\hline $\begin{array}{l}\text { Miscellaneous (affects } \quad \text { susceptible } \\
\text { crops) Nitrogen }\left(\mathrm{NO}_{3}-\mathrm{N}\right)\end{array}$ & $(\mathrm{mg} / \mathrm{l})<5$ & $5-30$ & $>30$ \\
\hline Bicarbonate $\left(\mathrm{HCO}_{3}\right)$ & $(\mathrm{mg} / \mathrm{l})<90$ & $90-500$ & $>500$ \\
\hline $\mathrm{pH}$ & $\begin{array}{l}\text { Normal Range } \\
6.5-8.4\end{array}$ & & \\
\hline
\end{tabular}

The Electrical conductivity (EC) of the river at Oba during the dry season is fairly constant at $0.07 \mathrm{dS} / \mathrm{m}$. This indicated that the minimum, maximum and mean value is constant. Thus, the coefficient of variance is zero. This implies that the salt concentration is fairly uniform. This may be attributed to the soil formation that, the soil does not add salt to the water within the sampling point in Oba river. However, the ranged value from 0.13 to $0.14 \mathrm{dS} / \mathrm{m}$ with a mean of 0.13 $\mathrm{dS} / \mathrm{m}$ in rainy season; the maximum limit for irrigation water was prescribed as $3 \mathrm{dS} / \mathrm{m}$ [22], this value fall into slightly to moderate in terms of degree of restriction in use. A lower EC value signifies less concentration of the dissolved ions and organic matters while salinity of water is an indication of high EC and TDS. The result revealed the presence of a varying degree of dissolved salts in the study water. This may have effect on the soil if it exceeds the maximum permissible value. However, the value of EC and TDS of water in the study area is within the permissible limit for irrigation. Thus, the water is suitable for irrigation use in terms of EC and TDS.

The range of concentration of bicarbonate $\left(\mathrm{HCO}_{3}\right.$ ) $)$ of the river at Oba during the dry season is fairly constant at 240 $\mathrm{mg} / \mathrm{l}$. This indicated that the minimum, maximum and mean value is constant. Thus, the coefficient of variance is zero. This implies that the bicarbonate $\left(\mathrm{HCO}_{3}{ }^{-}\right)$concentration is fairly uniform. However, concentration of bicarbonate in the rainy season ranged from 290 to $295 \mathrm{mg} / \mathrm{l}$, with the mean values of $293.33 \mathrm{mg} / \mathrm{l}$, as against the maximum permissible limit of $500 \mathrm{mg} / \mathrm{l}$ [22].This indicates that the value falls below the permissible limit. Bicarbonate, an important anion in irrigation water, is required in moderate concentration as found in the sampled water. At this concentration, bicarbonate brings about a change in soluble sodium percentage, hence regulate sodium hazard. High concentrations of bicarbonate ions in irrigation water may affect the uptake of mineral nutrients and their metabolism in the plant. Oba river has no traced of carbonate due to the $\mathrm{pH}$ of the water. At near-neutral values of $\mathrm{pH}$, dissolved bicarbonate $\left(\mathrm{HCO}_{3}{ }^{-}\right.$ ) is the dominant ion. A significant contribution from carbonate and other anions emerges only at pH levels greater than approximately 9.0 [24], [2].

Nitrate nitrogen $\left(\mathrm{NO}_{3}-\mathrm{N}\right)$ concentrations in the studied water in dry season ranged from 0.04 to $0.41 \mathrm{mg} / \mathrm{l}$ with a mean value of $0.16 \mathrm{mg} / \mathrm{l}$. However, in rainy season is fairly constant at $0.07 \mathrm{mg} / \mathrm{l}$, this indicated that the minimum, maximum and mean value is constant. This values fall below the limit of $30 \mathrm{mg} / \mathrm{l}$ recommended for standard irrigation water [31]. The Low level of $\mathrm{NO}_{3}-\mathrm{N}$ concentration in the water could be attributed to a low percentage of cropland within the study area that indicates lower nitrogen based fertilizer was used. This is similar to the findings of [9] and [18]. Nitrogen is a major nutrient needed by the plant, its abundance is desired in irrigation water; though low concentration of it (as in 
the water studied) does not make the water unfit for irrigation. Thus nitrogen concentration in the studied water poses no threat to its use for irrigation.

Sulphate $\left(\mathrm{SO}_{4}{ }^{2-}\right)$ concentrations in the sampled water in dry season ranged from 26 to $28 \mathrm{mg} / \mathrm{l}$ with a mean value of $26.67 \mathrm{mg} / \mathrm{l}$. The concentration of sulphate $\left(\mathrm{SO}_{4}{ }^{2-}\right)$ in the sampled water in rainy season rangedfrom 35 to $36 \mathrm{mg} / \mathrm{l}$ with a mean value of $25.33 \mathrm{mg} / \mathrm{l}$. Compared to the upper limit for irrigation ( $960 \mathrm{mg} / \mathrm{l}$ ), this value is within the acceptable limit. Sulphate is the primary form of sulphur in natural waters [26]. Plants primarily use sulphate as a sulphur source. However, oxidation of sulphur or sulphide in the soil can cause extreme acidity [26]. Nevertheless, discharges from industries as well as atmospheric precipitation could add significant quantities of sulphates to surface waters [17].

Phosphate concentration in the sampled water in dry season ranged from 0.08 to $0.11 \mathrm{mg} / \mathrm{l}$ with a mean value of $0.10 \mathrm{mg} / \mathrm{l}$. However, phosphate concentration in rainy season ranged from $0.11 \mathrm{mg} / \mathrm{l}$ to $0.12 \mathrm{mg} / \mathrm{l}$ with a mean value of $0.12 \mathrm{mg} / \mathrm{l}$. Phosphorus, though required in relatively large amounts by plants, is found in low concentration in the studied water. This is not strange; phosphorus has low concentration in natural waters as it is tightly bound to soil and aquifer sediments and not readily soluble [21]. The main source of agricultural and industrial phosphate is deposits of the mineral apatite-known as rock phosphate; though phosphorus occurs naturally in most geological formations and soils in varying amounts and forms [26]. Phosphorus in the studied water is unlikely to have its source from leachates from fertilizer and manure. This similar to the findings of [8], that phosphate concentration in Oba river water showed no correlation to fertilizer and manure use in an agricultural area. Low phosphorus concentrations in the studied Oba river water course poses no threat to its use as irrigation water and suggest a natural geologic sources have a greater influence on concentrations in surface water than anthropogenic sources.

Calcium $\left(\mathrm{Ca}^{2+}\right)$ concentrations in the studied water in dry season ranged from 36 and $38 \mathrm{mg} / \mathrm{l}$ with a mean value of $37.33 \mathrm{mg} / \mathrm{l}$. Calcium $\left(\mathrm{Ca}^{2+}\right)$ concentrations in rainy season ranged from 30 to $32 \mathrm{mg} / \mathrm{l}$ with a mean value of $31 \mathrm{mg} / \mathrm{l}$. This values falls below the maximum contamination limit for irrigation ( $400 \mathrm{mg} / \mathrm{l})$, this signify that the water is suitable for irrigation use.

Magnesium ( $\left.\mathrm{Mg}^{2+}\right)$ concentrations in the studied water in dry season ranged from 8 and $9 \mathrm{mg} / \mathrm{l}$ with a mean value of $8.33 \mathrm{mg} / \mathrm{l}$. Magnesium $\left(\mathrm{Mg}^{2+}\right)$ concentrations in rainy season ranged from 17 to $18 \mathrm{mg} / \mathrm{l}$ with a mean value of 17.67 $\mathrm{mg} / \mathrm{l}$. This values falls below the maximum contamination limit for irrigation $(61 \mathrm{mg} / \mathrm{l})$. It signifies that the water is suitable for irrigation use. None of the samples exceeded the threshold value irrespective of the point of collection, thus no threat. High concentrations of $\mathrm{Ca}^{2+}$ and $\mathrm{Mg}^{2+}$ ions in irrigation water will cause increase in soil $\mathrm{pH}$, leading to reduction in the availability of phosphorous to plants [33].

Sodium $\left(\mathrm{Na}^{+}\right)$concentrations in the studied water in dry season ranged from 1.28 and $1.46 \mathrm{mg} / \mathrm{l}$ with a mean value of $1.37 \mathrm{mg} / \mathrm{l}$. Meanwhile, in rainy season it ranged from 1.86 to $1.88 \mathrm{mg} / \mathrm{l}$ with a mean value of $1.87 \mathrm{mg} / \mathrm{l}$. Sodium (Na+) content is another major indicator when evaluating irrigation water quality. Sodium concentration less than $100 \mathrm{mg} / \mathrm{l}$ indicates no restriction, while concentrations greater than $100 \mathrm{mg} / \mathrm{l}$ shows moderate to high degree of restriction especially for sensitive crops [29]. Irrigation water with high sodium $\left(\mathrm{Na}^{+}\right)$content could cause the displacement of exchangeable cations, such as $\mathrm{Ca}^{2+}$ and $\mathrm{Mg}^{2+}$, from the soil clay minerals, which would be replaced by $\mathrm{Na}^{+}$[16], also stated that soils saturated by sodium peptize and they lose their permeability, leading to decrease in fertility and their suitability for cultivation. The Sodium $\left(\mathrm{Na}^{+}\right)$concentrations result indicates that, the river water samples is suitable for irrigation use as the sodium concentration is far below the maximum limit based on the guidelines proposed by [28] and [10] and the water is characterized by low sodium hazards.

The potassium $\left(\mathrm{K}^{+}\right)$concentrations in the studied water in dry season ranged from $2.40 \mathrm{mg} / \mathrm{l}$ and $2.50 \mathrm{mg} / \mathrm{l}$ with a mean value of $2.43 \mathrm{mg} / \mathrm{l}$. Potassium $\left(\mathrm{K}^{+}\right)$concentrations in rainy season ranged from $2.70 \mathrm{mg} / \mathrm{l}$ to $2.80 \mathrm{mg} / \mathrm{l}$ with a mean value of $2.77 \mathrm{mg} / \mathrm{l}$. Most of the minimum concentration exceeds the threshold value of $2 \mathrm{mg} / \mathrm{l}$. Inorganic fertilizers containing at least one of three basic nutrients; nitrogen, phosphorus, and potassium, are widely used in the study area to replenish crop and soil nutrients. Half to one- third of this fertilizer are absorbed by the crop and the remaining becomes residual in the soil and may join water body [5], [3]. Potassium is both an important fertilizer and common rocks constituent, high concentration of potassium ion found in the water could have been induced by leachates from agricultural fertilizer as observed by [23] or dissolution of rock constituent. Although, due to lower concentration of Nitrogen dissolution of rocks constituent is the most likely source of potassium in the sampled water. A major concern of high potassium concentrations in irrigation water is its deleterious effects on soil hydraulic properties, which has negative impacts on infiltration, water availability and plant growth [14]. High potassium and magnesium ion are typically found in recycled wastewaters, the presence of these two cations in high concentration in the surface water sampled might indicate seepage of wastewater into the underlying aquifer. 
The $\mathrm{pH}$ concentrations in the studied water in dry season ranged from 6.87 and 6.91 with a mean value of 6.89 . The $\mathrm{pH}$ concentrations in rainy season ranged from 7.15 to 7.33 with a mean value of 7.23.A comparison of the $\mathrm{pH}$ values with the normal range of standard irrigation water 6.0-8.4 by [12] showed that the samples are within the range for irrigation use. The mean $\mathrm{pH}$ values indicated that the river across the points of collection did not have alkaline. Although, application of irrigation water with $\mathrm{pH}$ outside the threshold could cause nutritional disparity or lead to toxic ion build up in the soil [29].Water with low $\mathrm{pH}$ tends to be acidic and may be corrosive. Such water could affect metallic plumbing fittings (leaching).

The salt concentration (TDS) in the water ranged from 33.30 to $34.10 \mathrm{mg} / \mathrm{l}$ with a mean value of $33.80 \mathrm{mg} / \mathrm{l} \mathrm{during}$ the dry season and ranged from 64.30 to $67.50 \mathrm{mg} / \mathrm{l}$ with a mean value of $66.30 \mathrm{mg} / \mathrm{l}$ in rainy season; The dispersion around the mean indicated that all the value falls below the mean and within the threshold value for irrigation purpose since the higher concentration is below the permissible limit of the standards $2000 \mathrm{mg} / \mathrm{l}[22]$, also according to irrigation water quality classification by [29], all the value falls below the mean and within the threshold value for irrigation purpose since the higher concentration is below $(<450 \mathrm{mg} / \mathrm{l})$ and they had no restriction to use for irrigation, The value of the coefficient of variation was $0.39 \mathrm{mg} / \mathrm{l}$, indicated that the TDS of water in the study area varied. This may be attributed to the geological formation of Ogbomoso which has an effect on the chemical content of surface water [3].

Table 4 Water quality indicators calculations for Oba river, dry and rainy season in

\begin{tabular}{lll}
\hline $\begin{array}{l}\text { Quality } \\
\text { Indicator }\end{array}$ & $\begin{array}{l}\text { Quality rate } \\
\text { dry season }\end{array}$ & $\begin{array}{l}\text { Quality rate } \\
\text { wet season }\end{array}$ \\
\hline SAR & 0.05 & 0.07 \\
KR & 0.02 & 0.03 \\
SSP & 2.28 & 2.62 \\
RSC & 1.37 & 1.79 \\
$\mathrm{PI}$ & 78.03 & 73.28 \\
$\mathrm{Mg} / \mathrm{Ca}$ & 0.37 & 0.95 \\
\hline
\end{tabular}

SAR: sodium adsorption ratio, meq/l; KR: Kelly's ratio, meq/l , RSC: Residual Sodium Carbonate, meq/l; SSP: Soluble Sodium Percentage, meq/l; $\mathrm{Mg} / \mathrm{Ca}$ :Magnesium/Calcium, meq/l and PI: Permeability Index, meq/l. Source: Author derived, 2019

Table 5 Summary of sampling points delineation under different limits (meq/l)

\begin{tabular}{|l|l|l|l|l|}
\hline SAR & Class & Mg/Ca & Class \\
\hline$<10$ & Excellent & $<1.5$ & Excellent \\
\hline $10-18$ & Good & $1.5-3$ & Excellent \\
\hline $18-26$ & Fair & $>3$ & Unsuitable \\
\hline$>26$ & Unsuitable & & \\
\hline KR & Class & SSP & Class \\
\hline$<1$ & Good & $<50$ & Safe \\
\hline$>1$ & Unsuitable & $>50$ & Unsuitable \\
\hline RSC & Class & PI & Class \\
\hline$<1.25$ & Suitable & $<25$ & Unsuitable \\
\hline $1.25-2.50$ & Doubtful & $25-75$ & Good \\
\hline$>2.50$ & Unsuitable & $>75$ & Excellent \\
\hline $\begin{array}{l}\text { SAR: sodium adsorption ratio; Mg/Ca: Magnesium-calcium ratio; KR: Kelly's ratio; SSP: soluble sodium percentage; PI: permeability index; RSC } \\
\text { residual sodium carbonate. Source: (Adhikary and Dash, 2012; Kerala,2014; Boateng et al., 2016) }\end{array}$
\end{tabular}




\subsection{Suitability of Oba river water in Ogbomoso for irrigation}

\subsubsection{Sodium adsorption ratio (SAR)}

The waters having SAR values less than $10 \mathrm{meq} / \mathrm{l}$ are considered excellent, $10 \mathrm{meq} / \mathrm{l}$ to $18 \mathrm{meq} / \mathrm{l}$ as good, $18 \mathrm{meq} / \mathrm{l}$ to $26 \mathrm{meq} / \mathrm{l}$ as fair, and above $26 \mathrm{meq} / \mathrm{l}$ are unsuitable for irrigation use [6]. In this work, the SAR values are lesser than $10 \mathrm{meq} / \mathrm{l}$ for the samples taken in dry and rainy season, therefore it is graded as excellent for irrigation use (Table 5). SAR is a measure of tendency of sodium ( $\mathrm{Na}$ ) ion to displace $\mathrm{Ca}$ ion in the irrigation water soil [32].

\subsubsection{Kelly's ratio $(K R)$}

The kelly's ratio of unity or less than one is indicative of good quality of water for irrigation whereas above one is suggestive of unsuitability for agricultural purpose due to alkali hazards [19]. From these figures, both in dry season as well as rainy season were observed to be 100 per cent good. The area has good quality water for irrigation purposes due to non alkali hazards in the water.

\subsubsection{Residual sodium carbonate (RSC)}

The residual sodium carbonate (RSC) did not exceed value of $2.5 \mathrm{meq} / \mathrm{l}$ in dry and rainy season; the water is generally suitable for irrigation. If the value of RSC is between $1.25 \mathrm{meq} / \mathrm{l}$ and $2.5 \mathrm{meq} / \mathrm{l}$, the water is marginally suitable (Table 5) while a value less than 1.25 meq/l indicates safe water quality [25]. In this respect, it is evident from (Table 4), that, RSC values in dry season as well as rainy season are less than $1.25 \mathrm{meq} / \mathrm{l}$ indicates safe water quality, suggesting that, the study location are under safe limit for irrigation use.

\subsubsection{Soluble sodium percentage (SSP)}

[10] has proposed classification scheme for rating irrigation waters on the basis of soluble sodium percentage (SSP). The values of SSP less than 50meq/l indicate good quality of water and higher values (i.e. $>50 \mathrm{meq} / \mathrm{l}$ ) shows that the water is unsafe for irrigation [6]. From these figures, it is observed that, 100 per cent of the water in dry season as well as rainy season has good quality water and safe for irrigation purposes.

\subsubsection{Permeability index (PI)}

The Permeability Index (PI)values > 75meq/l indicate excellent quality of water for irrigation. If the PI values are between $25 \mathrm{meq} /$ land $75 \mathrm{meq} / \mathrm{l}$, it indicates good quality of water for irrigation. However, if the PI values are less than $25 \mathrm{meq} / \mathrm{l}$, it shows unsuitable nature of water for irrigation (Table 4).Permeability Index (PI) of water is a function of sodium, calcium, Magnesium and carbonate in the soil [7], [11]. Based on this assessment, the water samples from this location indicate good quality of water in dry season as well as rainy season, therefore suitable for irrigation purposes.

\subsection{6. $\mathrm{Mg} /$ Ca ratio}

The concentration of magnesium ion is more important than that of calcium ion for irrigation water and their ratio serves as an index for irrigation water quality. The $\mathrm{Mg} / \mathrm{Ca}$ ratio of the river water is lower than the desirable limit values. $\mathrm{The} \mathrm{Mg} / \mathrm{Ca}$ ratio of $<1.5 \mathrm{meq} / \mathrm{l}$ indicates excellent quality of water for irrigation (Table 5). If the $\mathrm{Mg} / \mathrm{Ca}$ values are between $1.5 \mathrm{meq} / \mathrm{l}$ and $3 \mathrm{meq} / \mathrm{l}$, it indicates good quality of water for irrigation. Here, it was noted that the area have no magnesium hazard because the samples result of the area shows the ratio lesser than the desirable limit.

\section{Conclusion and recommendations}

The water samples results revealed that the area are under desirable limit and suitable for irrigationboth during the dry and rainy season as quality indices ranged from good to excellent uses. The ionic dominance for the major cations and the anions were in these order for the dry season; $\mathrm{Ca}^{2+}>\mathrm{Mg}^{2+}>\mathrm{K}^{+}>\mathrm{Na}^{+}$and $\mathrm{HCO}_{3}>\mathrm{SO}_{4}^{2-}>\mathrm{PO}_{4}>\mathrm{NO}_{3}$; while $\mathrm{Ca}^{2+}>$ $\mathrm{Mg}^{2+}>\mathrm{K}^{+}>\mathrm{Na}^{+}$and $\mathrm{HCO}_{3}^{-}>\mathrm{SO}_{4}^{2->} \mathrm{NO}_{3}^{-}>\mathrm{PO}_{4}$ is for rainy season. However, the water could be used on almost all soils with few danger of potassium in the water.

This study accents the need for regular Oba river water quality monitoring to assess pollution activity from time to time for taking appropriate management measures in time to mitigate the intensity of pollution activity. Because some of the parameters investigated such as potassium are very close to the upper limit. The remedial measures include:

- Famers should be encouraged to use biofertilizers and biopesticides to avoid the soil, surface water and groundwater contamination. 
- Action plan should be formulated for the short term and long term management for the efficient use of surface water resources and other natural resources after taking into account the population of the people, agricultural activities, availability of water resources etc.

- There should be a sustainable watershed management in place in order to protect the quality and quantity of Oba river. During the course of the study, it was discovered that there are a lot of human activities along the river bank. Such activities including irrigation with the use of agro-chemicals, cassava processing with effluent being discharged without treatment into the river.

- The study on Oba river should be extended beyond the limit of this work. This will help to provide complete information on the use of Oba river water for irrigation purposes.

\section{Compliance with ethical standards}

\section{Acknowledgments}

First of all, appreciation goes to small-scale farmers found in Oba river bank they helped a lot. Thanks also goes to the entire staff of Southern Guinea Research Station, Mokwa for the assistance one way or the other rendered during the work. Thanks to other individuals who had contributed unreserved participation during this work. God bless.

\section{Disclosure of conflict of interest}

This work is a collaboration of all the authors. All authors read and approved the final manuscript. The authors declare that they have no competing interests.

\section{References}

[1] Al-Sabah BJ.(2014). Evaluation of water quality index of Tigris river for irrigation purposesinAmara City, Southern Iraq. Kufa Journal for Agricultural Science., 6(4), 16-33.

[2] Sundararajan M and Sabarathinam C. (2014). Assessment of Groundwater Quality in and around Vedaraniyam, South India.

[3] Taiwo AM. (2016). Pollution Sources of Groundwater Quality in the Basement Rocks in Oyo State Nigeria Using Multivariate Statistics. Fresenius Environmental Bulletin25, 2284- 2291.

[4] Tay CK. (2007). Chemical characteristics of ground water in the Akatsi and Ketu Districts of the Volta Region, Ghana. CSIR- Water Research Institute. Accra, Ghana. West Africa Journalof Applied Ecology, 11, 1-23.

[5] Tomer MD and Burkart MR. (1998). Long-Term Effects of Nitrogen Fertilizer Use on Ground Water Nitrate in Two Small Watersheds, 2158-2171.

[6] USDA.(1954). 'Diagnosis and improvement of saline and alkali soils.' (U.S. Salinity Laboratory Staff, Government Printing Office, Washington D.C.).

[7] Vasanthavigar M, Srinivasamoorthy K, Rajiv Ganth R, Vijayaragharan K and Sarma VS.(2010). Characterization and quality assessment of groundwater with special emphasis on irrigation utility: Thirumanimuttar sub-basin, Tamil Nadu, India Arab. Geosci J.

[8] Welch HL, Survey USG, Kingsbury JA, Survey USG, Coupe RH and Survey USG. (2010). Occurrence of Phosphorus in Groundwater and Surface Water of Northwestern Mississippi., 142-155.

[9] Wick K, Heumesser C and Schmid E. (2012). Groundwater Nitrate Contamination: Factors and Indicators. Journal of Environmental Management1, 178-186.

[10] Wilcox LV. (1955). Classification and Use of Irrigation Water. Agric circ 969, Washington, DC: USDA., 1-19.

[11] Stewart BA and Nielsen DR.(1990). Irrigation of Agricultural Crops American Society of Agronomy., 1,218.

[12] Scherer TF, Seelig B and Franzer D. (1996). Soil Water and Plant Characteristics Important for Irrigation.

[13] Richards LA. (1954). Diagnosis and Improvement of Saline-Alkali Soils Agricultural Handbook no. 60, USDA

[14] Oster JD, Sposito G and Smith CJ. (2016). Accounting for Potassium and Magnesium in Irrigation Water Quality Assessment. California Agriculture70, 71-76. 
[15] Maia CEand Rodrigues KKRP. (2010). Relação entre bicarbonate e cloreto em águas parafins de irrigação (Relationship between carbonate and chloride in water for irrigation purposes). In: Workshop Internacional de Inovações Tecnológicas na Irrigação, 4, Fortaleza. Anais. Fortaleza, Brazil.

[16] MatthessG.(1982).The properties of groundwater, John Wiley, New York Sensing, 10, 1825-1814.

[17] Khudair BH. (2013). Assessment of Water Quality Index and Water Suitability of the Tigris River for DrinkingKumar D, Ahmed S (2003) Seasonal behaviour of spatial variability of groundwater level in a granitic aquifer in monsoon climate Cur Sci, 84(2), 188-196.

[18] Keeney D, Olson RA and Keeney D. (2014). Sources of Nitrate to Ground Water. Critical Reviews in Environmental Control16, 37-41.

[19] Karanth KR. (1987). Groundwater assessment development and management Tata McGraw Hill, New Delhi, 720.

[20] Islam MSand Shamasad SZ. (2009). Assessment of irrigation water quality of Bogra District in Bangladish. BangladishJ. Agric. Res.34, 59FMWR.

[21] Holman IP, Whelan MJ, Howden NJK, Bellamy PH and Willby NJ. (2008).Phosphorus in Groundwater - an Overlooked Contributor to Eutrophication? 5127, 5121-5127.

[22] FAO. (1985 and 1989). Water quality for agriculture Food and Agricultural Organization (FA0) of the United Nations. FAO, Irrigation and Drainage Paper 29, Rome Abdalla KAMAL EL-DIN, 1990 Water Management in oases.

[23] Falowo 00, Akindureni Y and Ojo 0. (2017). Irrigation and Drinking Water Quality Index Determination for Groundwater Quality Evaluation in Akoko Northwest and Northeast Areas of Ondo State, Southwestern Nigeria. American Journal of Water Science and Engineering3, 50-60.

[24] EL Ghandour MFM, Khali JB and Attal SA. (1985). Distribution of Carbonates, Bicarbonates, and PH Values in Ground Water of the Nile Delta Region, Egypt. Groundwater23.

[25] Cuena RH.(1989). Irrigation System Design Prentice Hall,Englewood Cliffs, NJ,552.

[26] Boyd CE. (2008). 'Water Quality' 2nd ed. (Auburn).

[27] Boateng TK, Opoku F, Acquaah SO and Akoto O.(2016). Groundwater Quality Assessment Using Statistical Approach and Water Quality Index in Ejisu-Juaben Municipality, Ghana. Environmental Earth Sciences, 75(6), 489.

[28] Bauder JW, Bauder TA, Waskom RM and Scherer TF.(2003).Assessing the Suitability of Water (Quality) for Irrigation - Salinity and Sodium. 1-5.

[29] Ayers RS and Westcot DW. (1985)."Water Quality for Agriculture” Food and Agriculture Organization of the United Nations.

[30] APHA. (2005). "Standard Methods for the Examination of Water and Wastewater" 21st ed.American Public Health Association Washington DC: USA Port City Press.

[31] Andreas P and FAO. (2007). Water Quality for Irrigation. In 'Handbook of Pressurized Irrigation Techniques'. 133.

[32] Al-Tabbal JA and KK Al-Zboon. (2012).Suitability assessment of groundwater for irrigation and drinking purpose in the Northern region of Jordan.J.Environ. Sci.Technol, 5, 274-290.

[33] Al-Shammiri MA, Al-Saffar Bohamad Sand Ahmed M. (2005).Waste Water Quality and Reuse In Irrigation in Kuwait Using Microfiltration Technology in Treatment Desalination;185, 213-225.

[34] Al-Sabah BJ.(2014). Evaluation of water quality index of Tigris river for irrigation purposes in Amara City Southern Iraq. Kufa Journal for Agricultural Science.6, 16-33.

[35] Adhikary PP and Dash CJ. (2012). Evaluation of Groundwater Quality for Irrigation and Drinking Using GIS and Geostatistics in a Peri-Urban Area of Delhi , India., 1423-1434.

[36] Sujatha Dand Rajeswara Reddy B. (2003). Quality characterization of groundwater in the south-eastern part of the Ranga Reddy district, Andhra Pradesh. Indian Journal of Environmental Geology, 44, 579-586.

[37] Status Report.(2007). Status report on water quality of water bodies and groundwater in Maharastra for the year 2004-2005. Hydrology Project (SW), Water Resources Department, Government of Maharastra. 
[38] Saidi S, Bouri S, Dhia HB and Anselme B. (2009). A GIS-based susceptibility indexingmethod for irrigation and drinking water management planning: Application to Chebba-Mellouleche aquifer, Tunisia. Agricultural Water Management, 96, 1683-1690.

[39] Olaniyi JO. (2006).Influence of nitrogen and phosphorus fertilizers on seed yield and quality of Wgusi melon (Citrullus lanatus (Thumb) Mansf) in Ogbomoso, Southwest Nigeria. Ph.D Thesis, University of Ibadan 57-155.

[40] Diersing N and Nancy F.(2009).Water quality: frequentlyasked questions.Florida Brooks National Marine Sanctuary, key West.

\section{How to cite this article}

Adegbola GA, Dauda M and Aluko TO. (2019). Assessment of the suitability of water quality for irrigation in Ogbomoso, Oyo State. GSC Biological and Pharmaceutical Sciences, 9(2), 21-31. 